\title{
Impact of Fair-Trade Certification on Worker Compensation in Indian Tea Estates: Interactions with The Plantations Labour Act
}

\author{
Akash Malhotra \\ Center for Economic Studies and Planning, Jawaharlal Nehru University, New Delhi, India \\ JEL classification: F16, J33, J81, K31, K42
}

Keywords:

Fair Trade, Compensation, Tea Estates, Plantations Labour Act, India.

\section{Abstract}

The plight of workers in the tea industry of India is widely acknowledged by both the government and the civil society across the globe. While the government of developing countries had been trying to alleviate the abysmal conditions of these workers through enactment of various laws, civil society in developed countries came up with initiatives like Fair-Trade to ensure better livelihood for these workers. This article explores the interactions between The Plantations Labour Act 1951 (PLA) and Fair-Trade (FT) hired labour standards in the context of tea plantations in India. The interactions tend to distort the compensation and welfare mechanisms set up by the state and even undermine the authority of the state. It was observed that FT labour standards offer a weaker vision of social justice for plantation workers than PLA. Further, Fair-Trade might reinforce the existing 'patrimonial' clientelism on plantations which, in first place, was induced by the codification of certain colonial practices into PLA. Fair-Trade certifiers need to rethink their approach for plantations and incorporate the effects of local state laws such as PLA while framing their labour standards. The delegation of management of FT premium fund to an independent third-party, such as an NGO, might correct some of the potential distortions and inefficiencies created by PLA. 


\section{Introduction}

Till recently, India was the largest consumer, producer and exporter of tea. The profits and operating margins of tea companies have been witnessing an upward trend, but the wages of the tea workers are the lowest among the entire organized sector (Gothoskar, 2012). Historically as well as in the present context, the tea plantations in India have maintained a distinct hierarchy and class structure among workers, management and owners of these estates. The same was observed in the prefatory notes to The Plantations Labour Act 1951 (PLA) "In spite of the fact that the plantation industry provides employment for more than a million workers, there is at present no comprehensive legislation regulating the conditions of labour in the industry..... In its report the Labour Investigation Committee observed "that as the conditions of the life and employment on plantations were deferent from those in other industries it would be very difficult to fit plantation labour in the general framework of the Industrial Labour Legislation without creating serious anomalies and recommended a Plantation Labour Code covering all plantation areas." " - an Act which came into force in 1955 and sought to improve the livelihood of plantation workers, who were otherwise brutally exploited and oppressed throughout the colonial era.

Till date, no state in India has included the tea industry in the schedule of employment in the Minimum Wages Act. In 1957, when the Indian Labour Conference (ILC) proposed the concept of a need based minimum wage, it received strong opposition from plantation owners. The owners argued that since at a plantation both parents are regular employees (an assumption that is often not true), one and a half consumption units should be the criteria for setting minimum wages as opposed to ILC's proposal of three consumption units. This reasoning, along with inclusion of in-kind benefits, have been accepted by the government on numerous occasions and it has, consequently, condoned the colonial practice of fixing 'subsistence wage' as 'minimum wage', thereby causing a continual depression in wages of plantation workers.

Another law governing the tea industry in India is the Tea Act 1953 which led to the constitution of the Tea Board of India. The Act confers wide powers to the Tea Board to supervise the smooth functioning of the tea industry and its plantations, including the power to take over tea estates that are not operating well (Gothoskar, 2012, p. 37). Around the same time and throughout the following years, various other laws bolstering worker rights — such as the Industrial Disputes Act 1947, the Employees' Provident Funds \& Miscellaneous Provisions Act 
1952, the Payment of Bonus Act 1965, the Payment of Gratuity Act 1972 etc. — were enacted. PLA itself has been amended directly or through other Acts from time to time; the most recent one being in 2010. It is a matter of grave concern and alarm that even after six decades of legislative advancement, the tea industry has been able to keep the wages of tea workers extremely low and living conditions insalubrious. This is partly attributable to the global structure of rewards in the tea industry which is heavily skewed away from the lowest rung of workers $-53 \%$ to retailer, $33 \%$ to blender, $7 \%$ to factory, $6 \%$ to trader, $1 \%$ to auction/broker and less than $1 \%$ to tea pickers (Morser and Michuki, 2010). This kind of distorted reward structure in agricultural commodity chains led to the birth of a social movement named "FairTrade" in the late 1980s by a church-based NGO in Netherlands which eventually spread to other developed nations of Europe and America as well. Fair-Trade (FT) seeks to provide fair prices to producers by eliminating/minimizing middlemen and improve the living conditions of small farmers and workers employed on farms. Fair-Trade certifiers have come up with labour standards which a farm or plantation must adhere to in order to receive and maintain FT certification. The literature on how these standards interact with the local state laws and what are the effects of those interactions on worker compensation and welfare is really scarce. The study of these interactions is going to be the central theme of this article. The rest of the article is organized as follows: Section 2 explains Fair-Trade, particularly in the context of plantations. Section 3 compares the voluntary fairness proposed by Fair-Trade with the legal fairness guaranteed by PLA. Section 4 studies the PLA induced clientelism in plantations in light of Fair-Trade and section 5 concludes with a couple of recommendations.

\section{Understanding Fair-Trade}

The concept behind Fair-Trade (FT) certification is to offer ethically-oriented consumers an opportunity to alleviate the condition of labour in developing and underdeveloped countries through the consumption of products priced at a premium and certified as originating from farms which follow good labour practices and sustainable production methods. This is broadly in line with Thurow's (1980) thesis on "green consumerism" which depicts the preference of upper middle-class consumers from industrialized societies for 'organic' as a part of their environmentalism and consumer activism. In this context, it is interesting to refer to findings from a multistore field experiment conducted by Hainmueller et al. (2015), wherein it was observed that when the generic placebo label was replaced by a FT label and prices raised by around 9\%, the demand (as measured by sales) declined by $30 \%$ for lower-priced coffee but 
remained steady for premium higher priced coffee. This indicates a significant heterogeneity among classes of consumers in attaching a value to ethical sourcing and its related certifications.

Nevertheless, the concept of Fair-Trade certification has been fairly successful as evidenced by its pervasiveness, with over 1.6 million FT-certified farmers and workers, located in 74 different countries and an impressive $€ 7.88$ billion sales in FT certified products (Fairtrade International, 2017).

The origin of Fair-Trade lies in an initiative taken up by a church-based NGO in Netherlands in response to a plunge in coffee prices in 1988 to ensure "sufficient wages" to coffee growers. To achieve this, a Fair-Trade label was created by this NGO which was then subsequently replicated in other countries of Europe and North America. In the present times, FairTrade USA (earlier known as TransFair USA) and Fair Trade Labelling Organization International (FLO) - an umbrella association of various labelling initiatives - are the dominant players in FT certification. The stated goal of these organizations is to improve the livelihoods and living conditions of small and marginal farmers and labour employed on farms in developing countries. This is meant to be achieved through two primary mechanisms:

1. Minimum Price: FT retailers/importers are required to buy the products, that are to be sold as FT products, at a minimum price set by FLO regardless of the market price. This guaranteed minimum price hedges the risk faced by farmers in a fluctuating commodity market and assures them a stable income.

2. Price premium: A price premium, in addition to the sales price, is paid to producers which must be set aside and allocated to projects that improve the quality of life of producers and their communities, as determined 'democratically' by producers themselves. A non-exhaustive list of potential projects that could be funded with the FT premium include investments in community infrastructure, building of schools and health clinics, improvements in water treatment systems, provision of educational scholarships, offering instruction courses to members of the community, including conversion to organic production, training in improved production practices, and the implementation of environmentally sustainable production. 
At the time of writing, the FT premium for tea stands at $\$ 0.50 / \mathrm{kg}$ of made tea and the FT minimum price, which is origin-specific, is currently $\$ 2.00-\$ 2.20 / \mathrm{kg}$ in India ${ }^{1}$. For a product to be sold with the FT label, every participant in the supply chain, including exporters, importers and other intermediaries, must be FT certified. The inclusion of commercial farms and enterprises like plantations that employ hired labour in FT certification has remained a bone of contention till date. The differences in approach and which crop plantation is to be included in FT certification even led to the withdrawal of FairTrade USA from FLO - the umbrella organization of all Fair-Trade initiatives — in 2011. Raynolds (2017) tracks the evolution of Fair Trade USA's position on certifying plantations producing crops other than tea or bananas ${ }^{2}$ and the role played by various private and institutional stakeholders in shaping the FairTrade USA's labour certification strategy.

\subsection{Can a plantation be 'fair'?}

With its emphasis on universal designs of individual rights and associated social justice facilitated through "direct trade", and dependence on international non-governmental certifiers, Fair-Trade echoes several of the fundamental doctrines of neoliberal economics. The neoliberal theory asserts that the individual liberty and freedom are best protected when institutions are built upon strong private property rights and free markets are the norm in the economy. Burrowed in this neoliberal logic, neoclassical economics espouses free market and minimum state intervention in the economy; and instead demands that the state act as a warden of the free markets and private property rights. This neoliberal logic paints the market (green consumerism) driven non-state actors such as FLO or FairTrade USA as the best regulators of capital and even-handed auditors of labour-capital equity, thereby challenging the ability/authority of the state to regulate and redistribute. Accordingly, FT certification could sometimes cause voluntary relinquishment of regulatory power by the state to these transnational certifiers/auditors, especially in cases where the state machinery is inept and weak, engendering 'new forms of institutional hardware'3. Besky (2008) provides an anecdotal evidence from a Darjeeling tea plantation ${ }^{4}$ corroborating the aforementioned argument.

\footnotetext{
${ }^{1}$ Source: FLO website (https://www.fairtrade.org.uk/en/farmers-and-workers/tea/about-tea) accessed on October 30, 2018.

${ }^{2}$ Note that tea and banana plantations have always received FT certifications; the issue mainly was the inclusion of coffee plantations in Fair-Tarde.

${ }^{3}$ Peck and Tickell (2002) finds these 'new forms of institutional hardware' emerging from a deregulatory political mindset, followed by technocratic economic management and invasive social policies.

${ }^{4}$ See Section 3
} 
However, Fair-Trade also extends beyond neoliberalism as it seeks to empower those conventionally having limited or no access to free market system. FT certification has emerged as an alternative channel for providing access to markets to "small producers" which otherwise remained excluded from the free market system either because of their size or a rent-extracting market-maker/ middlemen layer. This paradox of Fair-Trade has been recognized in the literature as well (Jaffee, 2007; Besky, 2008). For example, when large tea plantations captured the domestic market, the owners of smaller plantations turned towards the international markets to avoid being driven out of the market and losing their estates. The tea auction system, a relic of India's colonial past, limits the access of most, small tea planters to international buyers. The Darjeeling tea producers have to transport their tea over 400 miles to auctions in Kolkata where international buyers like Tetley and Lipton bid on it. These auctions are controlled by a cartel of large companies and traders who collude to keep the prices depressed (Samantha, 2005). Furthermore, many producers have to return to their estates without an ounce of their tea being sold whenever the supply exceeds the combined demand from international bidders and domestic buyers in these auctions. In this context, the opportunity to bypass the auction system and directly access export markets, at lucrative prices, serves as a major incentive for plantation owners to opt for FT certification.

Till date, most studies on the impact of FT certification have focussed on coffee producing regions, especially in Latin America and neighbouring geographies. The literature often focusses on how FT certification makes producers resilient to adverse price shocks, improves their livelihood and analyses the health and educational outcomes in the producer community (Murray et al., 2006; Arnould et al., 2009; Jaffe, 2014). Dragusanu, and Nunn (2018), while analysing the impact of FT certification on coffee producers from 1999-2014 in Costa Rica, found higher sales, revenues and profits associated with FT certification. As expected, these effects became more pronounced when the FT guaranteed minimum price was binding, i.e., the open market price coffee was less than the FT minimum price. FT certification had a direct sizeable positive effect on producer incomes as well as a significant (but smaller) positive spill over effect on the incomes of those not employed in the coffee industry but living in regions with FT production. A significant redistribution from intermediaries (those dealing in transportation, storage and sales) to skilled workers in coffee production was reported. Lastly, the authors observed positive effects of FT certification on the education (in terms of enrolment) of high-school-aged children and this positive outcome was attributed to the investment of FT premiums in scholarship programs. Arnould et al. (2009) found somewhat 
similar results for the economic impact of FT but uneven effects of FT participation on educational and health outcomes across three Latin American countries included in the survey. However, FT production in South Asia remains understudied with a few exceptions. Jena and Grote (2017), conducted a household survey of 256 small-scale coffee producers in a tribal community of southern India. They found a sizeable increase in incomes of households belonging to FT certified cooperatives, $\$ 49.62$ per hectare in one coffee season, to be precise. They also found that households who were not part of FT certified cooperatives had significantly lower incomes despite benefiting from the presence of FT certified cooperatives in the vicinity and a significant difference in per-capita income between households belonging to FT certified cooperatives and those who do not. Coffee and tea value chains and production setups are very different but the ethos behind Fair-Trade in these two commodities or for that matter any other commodity remains the same. Labels on boxes of all FT certified products tout to affluent consumers of the developed countries that the premium which they are paying for the product goes straight into the pockets of producers, or "empowered small farmers", to be precise. This is "supposed" to happen as Fair-Trade is purported to shorten the commodity chain by minimizing intermediaries and allowing "producers" to sell directly to international markets. Consumers seem to be happy because they are under the impression that they are "empowering small farmers" in the developing world through their consumption choices. This is reflected in consumers' willingness to pay, on an average, $10 \%$ above the market price for products with FT certification (Pelsmacker et al., 2006). The "producers", too, seem to be happy because they are getting a higher and stable price for their produce. On paper, Fair-Trade paints a jovial symbiosis between production and consumption.

However, the debate, on whether Fair-Trade really achieves its fundamental goal of improving livelihoods of poor producers, has been gaining traction in recent times within the economic literature as well as in public discourse (The Economist 2006). Beuchelt and Zeller (2011) show that even when prices for FT certified farmers were higher as compared to conventional markets, FT certification failed to improve the living standards of coffee growers in Nicaragua. Valkia and Nygren (2010) and Jena et al. (2012) had similar findings wherein the FT certification had only a limited impact on the livelihoods of small-scale coffee producers.

The marketing of FT certified coffee and tea might be done in a similar fashion and even might have a similar perception among consumers, but the way their production is organized generates different implications for the rank-and-file labour involved in their cropping. As opposed to coffee for which more than $70 \%$ of global output comes from small-scale farmers (FLO media release), most tea is produced on large plantations or estates and picked by 
employed workers. The Fair-Trade scheme was originally designed for workers or small farmers and was certainly not intended for planation managers or commercial farms. It is clear that the direct benefits of FT certification accrue to plantation management in the form of stable and higher prices and access to international markets. The fixed wage workers employed on these estates are expected to benefit indirectly through FT premium sponsored community development projects or by "safe" and "just" working conditions enforced by Fair-Trade standards. The scale and perception of benefits enjoyed by the plantation workers depend on enforcement of FT labour standards and how management "administer" the FT premiums respectively (see Section 4.1). The all-pervading authority of management on plantation workers' lives was succinctly described by a worker at Hattigor tea estate, Assam - "They are the court, they are the judge, they are the police." (Rosenblum and Sukthankar, 2014a, p. $67)$.

This ambiguity associated with FT certification of plantations is certainly not lost on scholars (Besky, 2008, 2010, 2014; Renard and Perez-Grovas, 2007; Sukhtankar and Rosenblum, 2014b). Fair Tarde certifiers themselves acknowledge these ambiguities and labour-owner inequities (FLO, 2014). As a result, Fair-Trade produce come primarily from small farmer cooperatives for almost all crops with a few exceptions. FLO allows certification of plantations for tea, bananas and some other fresh fruits ${ }^{5}$. The relaxation provided to tea and banana plantations raises the question of justice and fairness in FT certification of these plantations. What makes banana and tea plantations eligible for FT certification, while the other crops are not? The answer is the mismatch in supply and demand for FT labelled products. As most of the tea is produced on plantations, FT certifiers are left with no choice but to include plantations in order to meet the demand for FT labelled tea. But when it comes to coffee, the global market for coffee is too small to support both small farmers and plantations according to FLO, so there it is happy to include only small famers cooperatives and exclude large farms or plantations. In fact, Jaffe (2007) criticizes FT certifiers' willingness to include tea plantations or for that matter any plantations in FT certification.

In this context, it becomes imperative to ask a question - Can a plantation ever be "fair"? Besky (2014) insists that a plantation system is built on injustice and exploitation and ethical consumers cannot bring about change through their consumption of FT labelled products. Shedding light on the profound inequities deep rooted in the structure and history of tea

\footnotetext{
${ }^{5}$ FairTrade USA after its split from FLO in 2011 has expanded the ambit of crops for which plantations are allowed in FT certification.
} 
plantations in India, Sukhtankar and Rosenblum (2014b) wonder — " how there could be such a thing as 'fair' tea?'.

To get even close to the answer to the aforementioned question about 'fairness' of tea plantations, it is imperative to first understand the patron-client relationship existing between the labour and the owners of tea plantations and the laws furthering this relationship. This, along with other nuances of Fair-Trade certification of plantations and its interaction with local state laws, have been dealt in detail in the subsequent sections.

\section{Legal Fairness Vs. Voluntary Fairness: PLA and FT standards}

Shortly after its independence from British rule, the Indian parliament passed an Act intended to regulate the working conditions in plantations and ensure welfare of labour which came to be known as Plantation Labour Act, 1951 (PLA). In a way, this Act codified the British colonial cropping practices in a law (Besky, 2008). The Act applies to all tea, rubber, cinchona and coffee plantations in India. The Act precisely defines "employer", "plantation", "wages", "worker" and serves as an employment contract between workers and management of these plantations. The Act begins by providing "definitions" and then moves on to address pertinent topics in the subsequent chapters, viz., "inspecting staff", "provisions as to health", "welfare", "hours and limitation of employment", "leave with wages", "penalties and procedure", and "miscellaneous". The Act comprehensively defines the employment conditions to be followed. In addition, the Act mandates that the plantation owner/management provide sufficient supply of drinking water, clean sanitation and medical facilities for all workers. The Act guarantees housing and appropriate food rations to workers. The Act insists that educational facilities for children of workers and day-care facilities for working mothers be provided as well. The Act also lays down the procedure for inspection to check whether the provisions of this Act and rules made thereunder are being observed in the plantation and. The Act states the penalties for violation of rules made thereunder or contravention of provisions laid under the Act.

Superficially, one may perceive that PLA and FT standards might complement and fortify each other resulting in better and just environment for plantation workers. However, in reality, the picture seems to be quite different from the aforementioned notion. Besky (2008) narrates an anecdotal evidence from one particular tea plantation in Darjeeling, Dhokebari (a pseudonymous name), which allows us to infer a lot about how the dynamics between FT 
certification and the local state laws (PLA in our case) plays out. In the early 1990s, when FairTrade USA (then known as TransFair USA) was looking to expand its gamut of FT products, it approached the Dhokebari estate regarding FT certification primarily because its managers were adhering to the PLA which translated into "progressive" labour practices as far as FT certification is concerned. Eventually, Dhokebari became the first plantation of any kind to market its produce with an FT label. For workers of Dhokebari, the transition to FT standards was subtle and intangible, but what followed this certification was busting of labour unions, deteriorating health and education facilities and lowered food rations which made Besky (2008) suggest that the state is willing to see FT certification as a proxy for PLA mandated inspections which are meant to ensure estate's compliance with the standards stipulated in the Act. This suggestion is well founded given the absence of effective government enforcement as reflected in government's own statistics in which, effectively, no sanctions for violations are reported (Rosenblum and Sukthankar, 2014a, p. 67). The management tightly controls the visits by government inspectors and the workers report that these visits are never extended to their living quarters. The inspections and sanctions as specified in PLA to keep the management power in check exist only on paper, chiefly due to dysfunctional state machinery; this is well known to government which makes it more than willing to delegate its enforcement authority to these transnational non-governmental "independent" FT certifiers thence creating a new form of 'institutional hardware'.

This transfer of authority has the potential to cause a vicious downward spiral if the FT labour standards are weaker than state laws, or too abstract to be enforced properly, or if the certifiers do not audit these estates properly or are misled by the management. In this backdrop, it becomes essential to compare the efficacy of labour standards stipulated by FT certifiers with 'legally binding' mandates of Plantation Labour Act.

The hired labour standards, of both FairTrade USA (2017) and FLO (2015), for plantations are primarily based on the following four tenets:

i. Fair Labour conditions: No forced, bonded, or compulsory labor. Children and young workers are protected. Employment contracts and conditions are clear. Reasonable working hours. Safe work environment.

FT standards nebulously mentions that "Workers have a legally-binding written contract". In this context, it is important to understand that in addition to being a piece of law 
regulating plantations, PLA also serves as an employment contract between owners and plantation workers across India. PLA goes into much greater detail as to what fair employment conditions entail, for example, TradeFair USA standards vaguely states that "Workers receive rest days and paid breaks" whereas PLA provide for "a day of rest in every period of seven days" and "at least half an hour rest in every period of five hours work". Moreover, PLA also prohibits women and children from working during nightly hours (7 P.M. to 6 A.M.) over which FT standards remain silent.

ii. Fair wages and benefits: Wages and benefits meet or exceed legal minimums. Only legal, non-disciplinary wage deductions are permitted.

In this context, the FT standards does no better than PLA and puts the onus back on the local minimum wage laws, which in the case of India are quite messy. As per the Minimum Wages Act (1948), the minimum wages are set by state governments for each industry which has resulted in more than 1700 different minimum wage rates across a country delineated in just 29 states. But the main bone of contention here is the inclusion of in-kind benefits in the calculation of minimum wage for tea industry which allows plantation owners to not pay statutory minimum wages to the workers. As an example, consider the state of Assam, where the state-mandated minimum wage is INR 250 per day but the plantation workers "officially" receive only INR 137 for a day's work. However, the tea industry maintains that including the monetized value of other perks and facilities provided to workers, the daily pay-out is somewhere between INR 272 and INR 284. FT certifiers have seemed to accept such obscure calculations without any contention (Besky, 2008). The picture on ground seems grimmer than the official figures, with Besky (2008) reporting that workers at Dhokebari estate were receiving per unit payments, i.e., per kilogram of plucked tea, instead of daily wages as mandated by PLA. Issues related to paid leaves fail to find a place in "critical requirements" and is considered a "progress requirement" as per FairTrade USA (2017) hired labour standards whereas PLA explicitly guarantees one day of leave with wages for every 20 days of work done by an adult worker in addition to sickness and maternity leaves.

iii. Worker Welfare: Access to basic needs and services.

Over welfare issues like "housing standards", PLA offer more clarity than FT labour standards by laying down procedures for selection of sites for building of houses and size 
of plot, allotment, fixing of rent, if any, eviction etc. FairTrade USA labour standards simply specify that "Children living on-site have access to primary education and daycare"; PLA, on the other hand, enumerates the standards for these day-care "creches" in much more detail - lighting, ventilation, sanitation and a trained woman in-charge. Worker accessibility to essential goods and services, and that too at vaguely defined 'fair price', is only a "progress requirement" in FairTrade USA labour standards. PLA, on the other hand, is very definitive in this context and clearly specifies the amount of food rations to be provided per worker. In addition to laying provisions for "canteens", "medical facilities", "recreational facilities", PLA even takes care of smaller but important things like umbrellas, blankets, raincoats and other similar amenities for the protection of workers from cold and rain. Ignored in FT standards, PLA mandates appointment of welfare officers to ensure regular compliance.

iv. Democracy, Transparency and Community Development: Freedom of association and the right to collective bargaining. Workers Are Represented in a Fair-Trade Committee to Manage the Use of the Fair-Trade Premium.

The right to association and form labour unions is an essential trait of any democratic state founded on the rule of law and Article 19(1)(c) of the Constitution of India ensures this freedom of association and so the FT labour standards do not add much substance to worker empowerment in this regard and only specify that owners do not interfere with worker associations. However, the worrying scenario here is the dissolution of labour union post FT certification. Besky (2008) reports that before FT certification, Dhokebari workers were actively involved with pan-Darjeeling labour unions but after the estate received FT certification, the management was successful in dissolving the labour unions on the estate and subsequently, a Fair-Trade committee to manage the FT premiums, referred to as "Joint Body", took their place as "democratic representation of workers". FT hired labour standards stipulate that these FT committees be elected by premium participants (which includes workers as well) and the committee should meet with premium participants regularly. Besky (2008) and Makita (2012) highlights that these "Joint Bodies" do not meet regularly and are management appointed consisting only of supervisors and office staff. FT certifiers seem to take the word of management on these issues and not investigate further. In estates, where the labour unions were not dissolved, the members of these unions are still not allowed to be a part of the "Joint Body" (Makita, 2012). The management wanted the "Joint Body" to remain apolitical and was apprehensive that if allowed inclusion, the 
union-members might organise workers under the name of "Joint Body" and mis-utilize FT premiums to fund its anti-management activities. However, Besky (2008) assert that FairTrade committees such as "Joint Body" are not an adequate replacement for labour unions. Although there exist understaffed regional offices charged with enforcing PLA, the actual enforcement of PLA regulations could be ascribed to incessant negotiation between labour unions and plantation owners. In the absence of active labour unions, knowledge about PLA tends to deteriorate among workers and with it the infrastructure, food rations, medical facilities and work conditions (Besky, 2008). These local dynamics seem to be lost upon FT certifiers.

The two other general tenets of Fair-Trade revolve around Fair price and Direct Trade. The PLA is not meant to regulate these aspects of tea industry. But even on these fronts, FT general standards do not bring much benefit for plantation workers. The higher price fetched by FT label doesn't directly accrue to fixed-wage workers as all financial transactions occur through management and owners. Similarly, the direct trade facilitated through FT supply chain enables plantation owners to circumvent the auction system and sell directly to international buyers. In this context, the FT certification, with its purported aim of "empowering workers" and "eliminating middlemen", becomes paradoxical for plantations as it ends up benefiting the plantation owners who, as a matter of fact, are acting as middlemen between ethical consumers and real producers.

This is not to say that PLA is unassailable in all aspects of worker welfare. Under PLA stipulations, workers at Dhokebari were receiving $4 \mathrm{~kg}$ of flour and $2 \mathrm{~kg}$ of rice fortnightly which by no means is sufficient to sustain an extended family each worker supports (Besky, 2008). But, at least PLA addresses the problem of food security, which FT labour standards simply fail to acknowledge.

\section{Plantation Labour Act: Is Fair-Trade reinforcing the patrimonial clientelism between plantation workers and owners?}

Tea plantations in India, and their governance till date, are a legacy of British colonial rule. During its embryonic periods, the industry mainly recruited its workers from backward tribal and famine aggrieved areas (Singh et al., 2006). This was done with an ulterior motive of 
creating and maintaining a captive labour force at low wages, thus preventing the development of a free market for labour in tea industry (Chakrabarti and Sarkar, 2005). Families of labour were encouraged to settle on plantations which further served as an informal barrier to labour mobility (exit) and created a reproducible labour force for generations to come. Formally, the plantation workers were bound to serve for a fixed period by contractual laws (Workman's Breach of Contract Act 1859) or by some other coercive measures exercised by plantation owners which, under British administration, were conferred with powers to arrest and imprison workers who absconded without notice or refused to work (Chakrabarti and Sarkar, 2005; Behal and Mohapatra, 1992). The plight of plantation workers during these times were similar to those of 'bonded' labour (Gupta, 1992). These plantations, being located in remote areas, were cut-off from cities and villages and this isolation served to ghettoize these immigrated workers and their families in a kind of an enclave. Typically, a worker ended up being born, brought up, married (usually, within the plantation community), having children and dead at the same planation (Alawattage and Wickramasinghe, 2009). Inside these enclaves, the plantation owners were the law and treated their workers inhumanly, referring to them as 'uncivilised black barbarians' (Singh et al., 2006). Any mechanism for collective labour bargaining was absent at these planation's as workers were not allowed to unionize under the British rule (Chakrabarti and Sarkar, 2005). Alawattage and Wickramasinghe (2009) describes the relationship between plantation owners and workers in colonial India as a coercive 'masterservant' relationship. Makita (2012), equivalently labels this class structure existing on plantations during colonial times as a 'repressive' patron-client relationship.

The government of independent India, immediately after the adoption of the Constitution of India (1950), passed the Plantation Labour Act in 1951 to regulate the conditions of plantation labour generally. Unlike a standard employment contract, where the major chunk of compensation is in money wages, PLA legalized the entitlements which were otherwise being given arbitrarily and differentially to workers as incentives. This overt acceptance of traditional values led to legal recognition of the existing clientelism on plantations. Unionization right granted by Article 19(1)(c) of the Constitution of India and other provisions in PLA, like regulation of working conditions and provisions for inspection, certainly bolstered workers' rights. The overall result of these slew of laws passed in a short period of time was that it transmuted the patron-client relationship existing between plantation owners and workers from 'repressive' to 'patrimonial'. 
The government of independent India, immediately after the adoption of the Constitution of India (1950), passed the Plantation Labour Act in 1951 to regulate the conditions of plantation labour generally. Unlike a standard employment contract, where the major chunk of compensation is in money wages, PLA legalized the entitlements which were otherwise being given arbitrarily and differentially to workers as incentives. This overt acceptance of traditional values led to legal recognition of the existing clientelism on plantations. Unionization right granted by Article 19(1)(c) of the Constitution of India and other provisions in PLA, like regulation of working conditions and provisions for inspection, certainly bolstered workers' rights. The overall result of these slew of laws passed in a short period of time was that it transmuted the patron-client relationship existing between plantation owners and workers from 'repressive' to 'patrimonial'. In such contexts, Scott (1972) has identified five patron-to-client flows as markers of relatively 'patrimonial' clientelism, viz., basic means of subsistence, protection, subsistence insurance in times of crisis, collective patron services, and brokerage and influence on behalf of clients. All five of these markers could be observed in plantations functioning in compliance with the PLA. As stipulated by PLA, the plantation owners provide workers with steady employment, housing and other basic services to guarantee subsistence. In years of poor harvest or commodity price crash, the management is expected to absorb all losses and not cut back on worker wages or amenities, an implicit assumption in PLA. The management is responsible for providing medical facilities to the workers, as per PLA, and often provide loans or grants to workers' families.

\subsection{Fair-Trade: in the light of 'patrimonial' clientelism}

The costs of acquisition and renewal of FT certification are borne by plantation owners. Makita (2012) argues that FT certification of plantations can be interpreted as an instance of 'brokerage' function; where the owners of plantations (the patron), in line with Scott (1972) characterization, negotiates and extract rewards (FT premiums) from the outside for the benefit of workers (clients) by acquiring and retaining FT certification. While studying the impact of FT certification on worker compensation in presence of PLA, it becomes imperative to also understand any second-order effects the PLA might have, like how the 'patrimonial' clientelism on plantations would interact with FT certification.

Makita (2012) surveyed 62 households living in a community on Sonahpur tea estate (a pseudonym), located in Darjeeling district of West Bengal, which included seven worker settlement villages delineated into nine communities. Through semi-structured interviews, the 
data was collected on workers' perception of Fair-Trade benefits (lbid.). At the time of the survey, the Sonhapur estate had experienced 15 years of Fair-Trade certification $60-80 \%$ of its total export went to FT markets, which leads to the expectation that Fair-Trade practices might have fairly permeated this tea estate. FairTrade USA (2017) and FLO (2015) guidelines stipulate that FT premiums must be managed and invested through a democratically elected committee (commonly known as 'Joint Body') representing labour and allow only a minority representation of management in these committees.

However, in the case of Sonahpur it was observed that the rank-and-file workers were barely aware of Fair-Trade premiums and were unaware of the selection process of these Joint Bodies which led Makita (2012) to conclude that Joint Body members were being appointed by the management and not elected by workers which was corroborated by the interview of Chief Manager who conceded:

"Some trade-union members asked me to choose them as members of the Joint Body. We [the management] refused their offer because the Joint Body should be a non-political organisation."

This statement and the usage of the verb "choose" plainly reflects the hegemony of management over the selection process of members of the Joint Body, which is in clear violation of FT standards. This is also indicative of the fact that existing labour unions are also excluded form committees which operate FT premium funds. Of the total 62 households surveyed, only half (33) had some kind of knowledge about the Joint Body (See Table 1) but none were about the financial source of the fund being administered by the Joint Body' grants from plantation management or donations from foreign charities were their best guesses (Makita, 2012).

Unaware of Fair-Trade, workers were still enjoying substantial benefits from its premiums, as per their own acknowledgement (See Table 2). About 65\% of the households reported of receiving welfare assistance additional to benefits and services stipulated by PLA. Oblivious to the source, funding these assistances, 'many' of the workers attributed the increases welfare to management's largesse. Consequently, those workers who were benefited by the programs funded by FT premiums were now showing more gratitude towards plantation owners and 
management. This led Makita (2012) to conclude that Fair Trade, and its associated invisibility among workers, led to the reinforcement of 'patrimonial' clientelism in tea estates.

Table 1: Households' awareness of Joint Body

\begin{tabular}{|l|c|}
\hline Perception Level & No. of households \\
\hline Never heard & 11 \\
Know only by name & 18 \\
Have some knowledge & 33 \\
Know some members only & $(10)$ \\
Know some activities only & $(9)$ \\
Know some members and activities & $(14)$ \\
\hline \multicolumn{2}{|c|}{ Total } \\
\hline
\end{tabular}

Source: Makita (2012)

Table 2: Households' perceptions of additional welfare assistance

\begin{tabular}{|l|c|}
\hline Perceived Benefit & No. of households \\
\hline Rot received anything & 22 \\
Received & $40^{6}$ \\
Loans from the Joint Body & $(15)$ \\
Loans from the estate & $(19)$ \\
Cash grant from the Joint Body & $(1)$ \\
Cash grant from the estate & $(8)$ \\
Materials from the estate (for bio-gas) & $(1)$ \\
Temporary employment from the estate (tree & $(1)$ \\
planting) & \\
Training (medical) from the Joint Body & $(1)$ \\
\hline \multicolumn{1}{|c|}{ Total } & 62 \\
\hline
\end{tabular}

Source: Makita (2012)

${ }^{6}$ The break-up might not add to the total as some households reported more than one kind of benefits. 


\subsection{Third Party Involvement: impact on perceived benefits and clientelism}

During 2005-2008, the management of Sonahpur estate went into an agreement with an NGO named Community Health Advancement Initiative (CHAI) wherein they agreed to invest a part of FT premiums through CHAI and its projects involving construction of roads, water supply system, community centres, footpaths, playgrounds etc. The CHAI took a participatory community development approach under which it held meetings with community members to discuss and understand their welfare needs. This resulted in a significant uptick in participation rate with 54 out of 62 surveyed household reporting participation in these meetings (see Table 3).

Table 3: Households' perception of CHAI project

\begin{tabular}{|l|c|}
\hline Perception levels & No. of households \\
\hline Never heard & 4 \\
Know only by name & 18 \\
Participated in the meetings but not benefited & 36 \\
Participated in the meetings and benefited & 62 \\
\hline \multicolumn{1}{|c|}{ Total } & \\
\hline
\end{tabular}

Source: Makita (2012)

Even those who were actively participating in CHAI project meetings were unaware of the fact that a significant chunk of the funding for these projects was coming from FT premiums. The third-party involvement had no impact on awareness about Fair-Trade among workers, and simply caused a shift in the belief of workers, who were now under the impression that the development projects were gifts from NGO as opposed to 'many' believing earlier that additional welfare assistance was engendering from management's generosity. From this, Makita (2012) infers that administration of FT premium fund by a third-party such as CHAI did not alter existing patron-client relationships on the tea estate.

Overall, Makita (2012) does a facile analysis and misses important interactions such as the impact of worker expectations from and experience of existing clientelism on the estate while measuring perceived benefits which might have led to under or over-reporting in the case of management appointed Joint Body. The participation rate certainly shot up from $0 \%$ to $87 \%$ 
when FT premium fund was being administered by a third party like CHAI as compared to the management appointed Joint Body. However, on surface, the survey data reflects a drop in number of households receiving perceived benefits from 40 (see Table 2) to 36 (see Table 3) when the FT premium fund administration is partially shifted from Joint Body to a third-party NGO. Does this depict a trade-off between participation rate and benefits (perceived)? Not necessarily, as the two numbers are not directly comparable for mainly two reasons; firstly, the benefits and services under the lens are different in the two contexts, and secondly the numbers don't depict the depth or utility derived by any worker from those perceived benefits - it merely represents a count. Makita (2012) do not try to measure the actual socio-economic benefits of additional welfare assistances and CHAI projects which could have facilitated an efficiency comparison between the Joint Body and CHAI. An index of perceived benefits could have also done the same job but from workers' utility point of view. The qualitative inference about FairTrade significantly reinforcing patron-client relationship on the estate when its premiums are managed by Joint Body does not reflect much on the strength of reinforcement (whether it is statistically significantly different from zero or not), as the number of households exclusively believing additional welfare assistance to be coming from management's generosity (and not from foreign donors) is obscured by the usage of 'many' in the analysis.

\section{Conclusion}

As a concluding remark, it is adequate to say that the Plantation Labour Act is a much more detailed, exhaustive and well-drafted than FT hired labour standards and certainly offer a stricter vision of social justice for plantation workers. The abstract tenets of Fair-Trade fail to account for regional variability and tend to overlook how local laws, state capacity and indigenous practices when interacted with FT standards could create unintended consequences for the rank-and-file workers - the social class which it pledges to empower. This fixation on universal standards pursued by FT certifiers reverberates of neo-liberalization and the associated vision of a single global free market. Under FT labour standards, the worker unions are diluted to "democratically-elected" Fair Trade committees which, in reality, are nothing more than puppets of management; in the absence of unions the enforcement of local state laws protecting labour rights begin to ebb. As a consequence of both voluntary relinquishment and indirect weakening, Fair-Trade undermines the authority of state and its laws, thence bolstering the neoliberal logic and supplanting sate-institutions with new forms of institutional hardware. FT certifiers must take knowledge of these trends and tailor their labour standards in 
accordance with state laws such as PLA. If the FT hired labour standards for plantations are only acting as a subset of PLA, then, in their current form, they are of not much use in empowering or ensuring fair compensation to workers. FT certifiers must either expand the gamut of welfare aspects or go into the detailed specifications and try to fill in the lacunae left by PLA and the state bureaucracy such as minimum wages, gender discrimination, effectual monitoring etc.

Under the current hierarchy in plantations and provisions of PLA, the workers do not have an equal employer-employee relationship with owners but are rather subjected to a traditional patron-client relationship deriving from the colonial past. Makita (2012) survey data hints that Fair-Trade might be reinforcing the 'patrimonial' clientelism on plantations. The unawareness about Fair-Trade among rank-and-file workers, as corroborated by many studies (Besky, 2008; 2010; Makita, 2012), does distort their perception of welfare projects being funded by FT premiums. The "democratically-elected" committees representing workers, as stipulated by FT standards, are, in reality, nothing more than management 'appointed' Joint Bodies. In this scenario, it is technically possible for management to (mis)utilize FT premiums to meet the PLA obligations and further to discriminate between workers for various reasons ${ }^{7}$. The participatory utilization of FT premium fund seems unfeasible in the existing top-down hierarchy on plantations where there is little or no scope of bottom-up communication. Even if lowest rung of workers and sub-staff members are included in the Joint Bodies they might not be willing to question the decisions of managers/owners regarding fund investment. From here, the way forward is either complete exclusion of management from FT premium management committees or intermediation by a third-party. The complete exclusion might not be practically feasible as most of the workers are uneducated or lowly educated and might have a difficult time in understanding the system of Fair-Trade premiums and optimal investment strategies. The conflation of fund management bodies with already existing and politically affiliated labour unions is likely to receive strong opposition from plantation owners as they are the ones paying the registration and renewal fees for FT certification and might not tolerate the utilization of FT premiums by unions for their radical anti-management activities.

As demonstrated by Makita (2012), an independent organisation, like CHAI, could facilitate participatory development by effectively communicating across different strata of hierarchy

\footnotetext{
${ }^{7}$ Makita (2012) observed that microcredit from FT premium fund was being screened and disbursed to workers on the basis of a manger's discretion in Sonahpur estate. Later, the entire microcredit program was suspended by the management without any explanation.
} 
existing on plantations and would certainly not bolster the 'patrimonial' clientelism, when there is unawareness about Fair-Trade among workers (which is almost always the case). FT certifiers must take cognizance of the evidence that audits and inspections, both by private and public officials, are tigtly controlled by the management and have not proven effective in wresting compliance to either standards or state laws (Rosenblum and Sukthankar, 2014a). FLO and TradeFair USA may consider tweaking their plantation certification approach by mandating the administration of FT premium fund by an independent third-party and also playing a central role in the selection of such intermediary organizations to prevent collusion between management and this independent organization. However, in this regard, FT certifiers must remain chary of vultures of financial industry searching for fat fund management fees and, in my opinion, should only allow not-for-profit or charities as intermediaries. The intervention by a third-party offers a promising solution, but is it an apposite (or better) substitute for untampered "democratically elected" committees? The question remains unanswered. 


\section{References}

1. Alawattage, C. and Wickramasinghe, D. (2009) 'Institutionalisation of Control and Accounting for Bonded Labour in Colonial Plantations: A Historical Analysis', Critical Perspectives on Accounting 20(6): 701-15

2. Arnould, E. J., Plastina, A., \& Ball, D. (2009). Does fair trade deliver on its core value proposition? Effects on income, educational attainment, and health in three countries. Journal of Public Policy \& Marketing, 28(2), 186-201.

3. Behal, R. P. and Mohapatra, P. P. (1992) "Tea and Money versus Human Life": The Rise and Fall of the Indenture System in the Assam Tea Plantations 1840-1980', Journal of Peasant Studies 19(3\&4): 142-72.

4. Besky, S. (2008). Can a plantation be fair? Paradoxes and possibilities in fair trade Darjeeling tea certification. Anthropology of Work Review, 29(1), 1-9.

5. Besky, S. (2010). Colonial pasts and fair trade futures: Changing modes of production and regulation on Darjeeling tea plantations. Fair trade and social justice: Global ethnographies, 97-122.

6. Besky, S. (2014). The Darjeeling distinction: Labor and justice on Fair-Trade tea plantations in India. Berkeley, CA: University of California Press.

7. Chakrabarti, A. M. and Sarkar, K. (2005) Productivity and Labour Welfare: A Study in Tea Gardens. Kolkata: State Labour Institute, Government of West Bengal.

8. Dragusanu, R., \& Nunn, N. (2018). The Effects of Fair Trade Certification: Evidence from Coffee Producers in Costa Rica (No. w24260). National Bureau of Economic Research.

9. FairTrade USA. (2017). Agricultural Production Standard, Version 1.0.0. Oakland, CA. Fair Trade USA.

10. FLO (2014) http://fairtradeindia.org/blog/fairtrade-tea-in-india/ Accessed on Sep 1, 2018

11. FLO. (2017). Fairtrade Standard for Hired Labour, Version 15.01.2014_v1.4. Bonn, Germany. Fairtrade International.

12. Gothoskar, S. (2012). This Chāy Is Bitter: Exploitative Relations in the Tea Industry. Economic and Political Weekly, 33-40.

13. Gupta, R. D. (1992) 'Plantation Labour in Colonial India', Journal of Peasant Studies 19(3\&4): 173-96. 
14. Jaffee, D. (2014). Brewing justice: Fair trade coffee, sustainability, and survival. University of California Press.

15. Makita, R. (2012). Fair trade certification: The case of tea plantation workers in India. Development Policy Review, 30(1), 87-107.

16. Morser, A., \& Michuki, G. (2010). A Bitter Cup: The Exploitation of Tea Workers in India and Kenya Supplying British Supermarkets. War on Want.

17. Murray, D. L., Raynolds, L. T., \& Taylor, P. L. (2006). The future of Fair Trade coffee: dilemmas facing Latin America's small-scale producers. Development in practice, 16(02), 179-192.

18. Peck, J., \& Tickell, A. (2002). Neoliberalizing space. Antipode, 34(3), 380-404.

19. Pelsmacker, P. D., Janssens, W., Sterckx, E., \& Mielants, C. (2006). Fair-trade beliefs, attitudes and buying behaviour of Belgian consumers. International Journal of Nonprofit and Voluntary Sector Marketing, 11(2), 125-138.

20. Ranjan Jena, P., \& Grote, U. (2017). Fairtrade certification and livelihood impacts on small-scale coffee producers in a tribal community of India. Applied Economic Perspectives and Policy, 39(1), 87-110.

21. Rosenblum, P., \& Sukthankar, A. (2014a). The More Things Change. The World Bank, Tata and Enduring Abuses on India's Tea Plantations (New York: Columbia Law School Human Rights Institute).

22. Samantha, G. (2005). Tea Break: A Crisis Brewing in India. Action Aid, UK

23. Scott, J. C. (1972b). The Erosion of Patron-Client Bonds and Social Change in Rural

24. Singh, S. N., Narain, A. and Kumar, P. (2006) Socio-Economic and Political Problems of Tea Garden Workers. New Delhi: Mittal Publications.

Southeast Asia. Journal of Asian Studies 32(1): 5-37.

25. Sukthankar, A., \& Rosenblum, P. (2014b). Can there be a 'socially responsible' tea? https://kafila.online/2014/02/23/can-there-be-a-socially-responsible-tea-ashwinisukhtankar-and-peter-rosenblum/ Accessed on Sep 1, 2018

26. The Economist. 2006. Voting with Your Trolley. December 7 https://www.economist.com/special-report/2006/12/07/voting-with-your-trolley. Accessed on Sep 1, 2018

27. Valkila, J., \& Nygren, A. (2010). Impacts of Fair Trade certification on coffee farmers, cooperatives, and laborers in Nicaragua. Agriculture and Human Values, 27(3), 321333. 